\title{
Karpuz Çay Deltasının (Antalya Doğusu) Paleojeomorfolojisi
}

\author{
Paleogeomorphology of Karpuz Çay delta
}

\author{
İhsan Çiçek ${ }^{1 *}$, Necla Türkoğlu ${ }^{1}$, Gürcan Gürgen ${ }^{2}$ \\ ${ }^{1}$ Ankara Üniversitesi, Dil ve Tarih-Coğrafya Fakültesi, Coğrafya Bölümü, Ankara \\ ${ }^{2}$ Ankara Üniversitesi, Egitim Bilimleri Fakültesi, Sosyal Bilimler Eğitimi Bölümü, Ankara
}

Öz: Antalya körfezinin doğusunda Karpuz Çay ve Acısu tarafindan oluşturulan klyı ovası, daha çok alçak tepelik alanlarla çevrelenmiştir. Akdeniz klyılarının genç ovalarından biri olan klyı ovası, günümüzden yaklaşı 4000 yıl önce gelişmeye başlamıştır. Çalı̧̧ma alanında jeomorfolojik birimler, genel olarak, Miosen yaşlı Karpuz Çay ve Alt Üst Pliosen yaşll Yenimahalle formasyonları üzerinde gelişmiştir. Deniz çekilmesinin Geç Pliosen'de gerçekleşmesinden dolayl yöredeki en eski morfolojik birimler, Enalt Pleistosen yaşlı aşınım yüzeyleridir. Çalışma alanının paleocoğrafik evrimini ortaya koymak amactyla yapılan sondajlardan elde edilen örneklerin incelenmesi, $C^{14}$ tarihlendirmesi ve laboratuar analizleri sonucunda 6 farkl dönem ortaya konulmuştur. Ortam koşullarının belirlenmesinde arazinin morfolojik özellikleri yanında makro fosillerden de yararlanulmiştır. Elde edilen fosillerden Bivalvialardan Cardium edule ve Gastropoda türlerinden Cerithidea insulaemaris, Tegula pulliga, Gyraulus intermixtus ve Turritella terebra türleri tanımlanmıştır. Bu türlerin ekolojik özellikleri dikkate alındığında bölgenin sığ denizel etki altında kaldı̆̆g, zaman zaman acısu ve tatlı su özelliği gösterdiği belirlenmiştir.

Anahtar Kelimeler: Karpuz Çay, Antalya Neojen Havzasl, Geç Pleistosen-Holosen, Alüvyal Jeomorfoloji, RC ${ }^{14}$

Abstract: The costal plain formed by Karpuz Çay and Aclsu at the east of Antalya Bay is surrounded by low hilly area. This costal plain, which approximately started to form 4000 years ago, is one of the young plains of Mediterranean coasts. In the area under investigation, the geomorphologic units developed on Miocene aged Karpuz Çay and Early-Late Pliocene aged Yenimahalle. Since the drop of sea level occured in Late Pliocene, the oldest morphologic unit in the area is Early Pleistocene aged denudation surfaces. To determine the paleogeographic evolution of the area, the samples taken from boreholes were analyzed. From the results of laboratory analysis and $C^{I 4}$ tests, six different period has been identified. To determine the environmental conditions, the morphologic features of the area and the macro fossils are used. From the analysis of samples containing macro fossils, the Cardium edule from Bivalvia family, Cerithidea insulaemaris, Tegula pulliga, Gyraulus intermixtus and Turritella terebra from Gastropoda family were identified. As the ecologic conditions were considered, it was determined that the area is under the influence of sea, and time to time the area was developed fresh water and salt- water features.

Keywords: Karpuz stream, , Antalya Neogene Basin, Late Pleistocene-Holocene, Alluvial geomorphology, RC $C^{14}$

\footnotetext{
* İletişim yazarı: İ.Çiçek, e-posta: cicek@humanity.ankara.edu.tr
} 


\section{Giriş}

Çalışma alanı Antalya körfezinin doğusunda, Manavgat şehir merkezine $12 \mathrm{~km}$, Side'ye $15 \mathrm{~km}$ uzaklıktadır. $51,4 \mathrm{~km}^{2}$ 'lik çalışma alanında alüvyal ova karakterini yansıtan, yükseltisi 10 metreden daha düşük yerler $19 \mathrm{~km}^{2}$ dir (Şekil 1). Kıyı çizgisine paralel uzanan ova, kuzeybatı-güneydoğu yönünde yaklaşık $7 \mathrm{~km}$, kuzeydoğu-güneybatı yönünde ise yaklaşı $3,5 \mathrm{~km}$.dir.

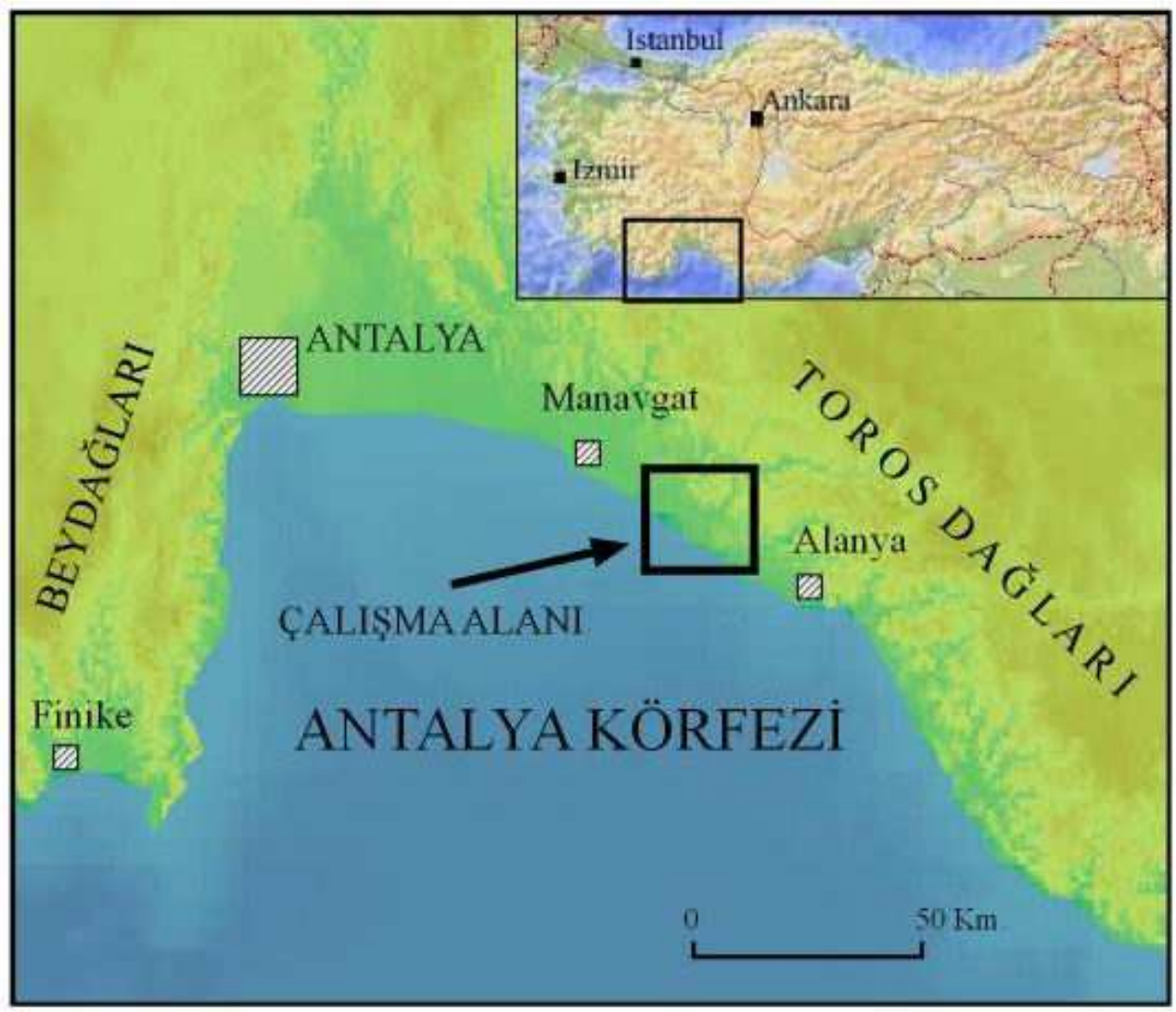

Şekil 1. Çalışma alanının lokasyon haritası

Çalışma alanı ve yakın çevresi alçak kıyı özelliğinde olup, bu alanda fazla yüksek birimler bulunmamaktadır. Ovayı çevreleyen tepelik alanlar basamaklar halinde kademeli şekilde yükselmektedir (Foto 1; Şekil 2). 


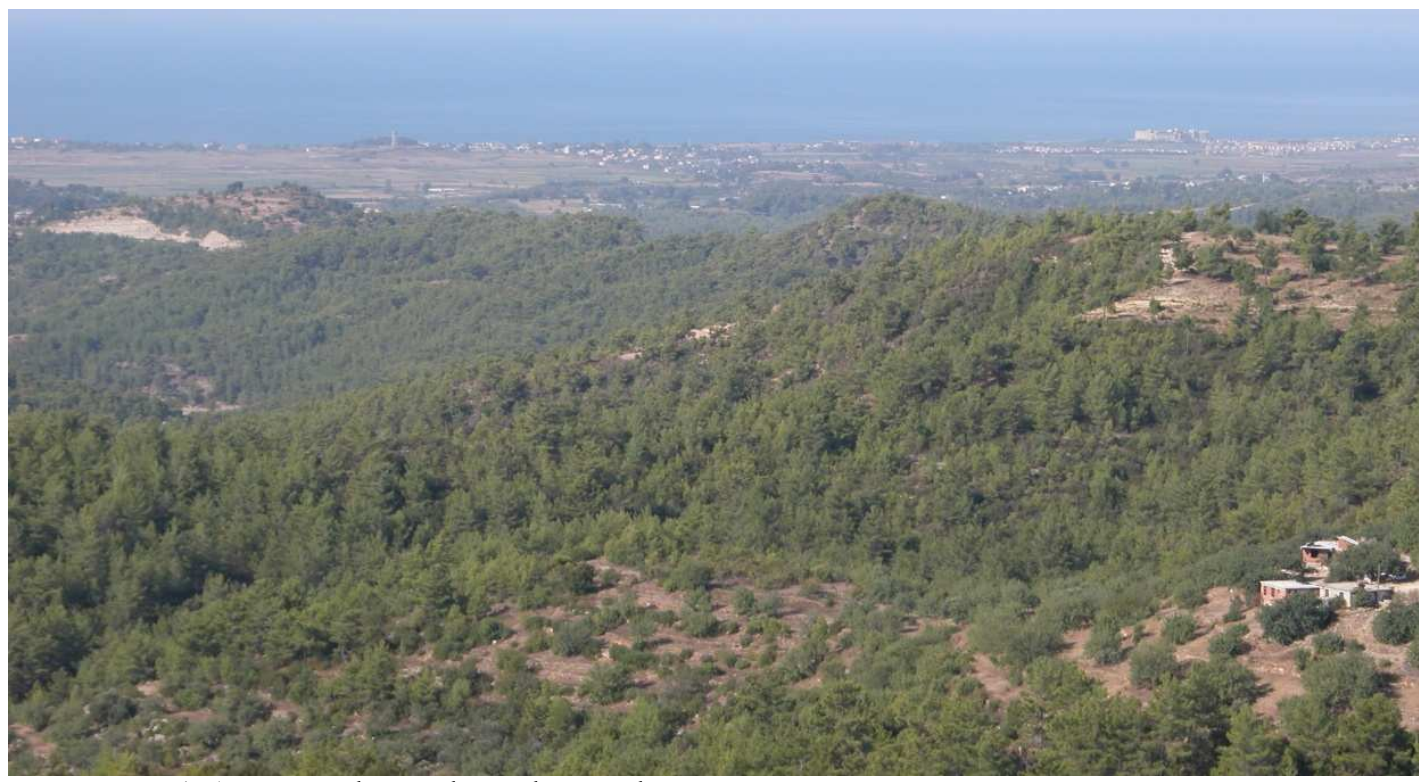

Foto 1. Araştırma alanının kuzeyden genel görünüşü.

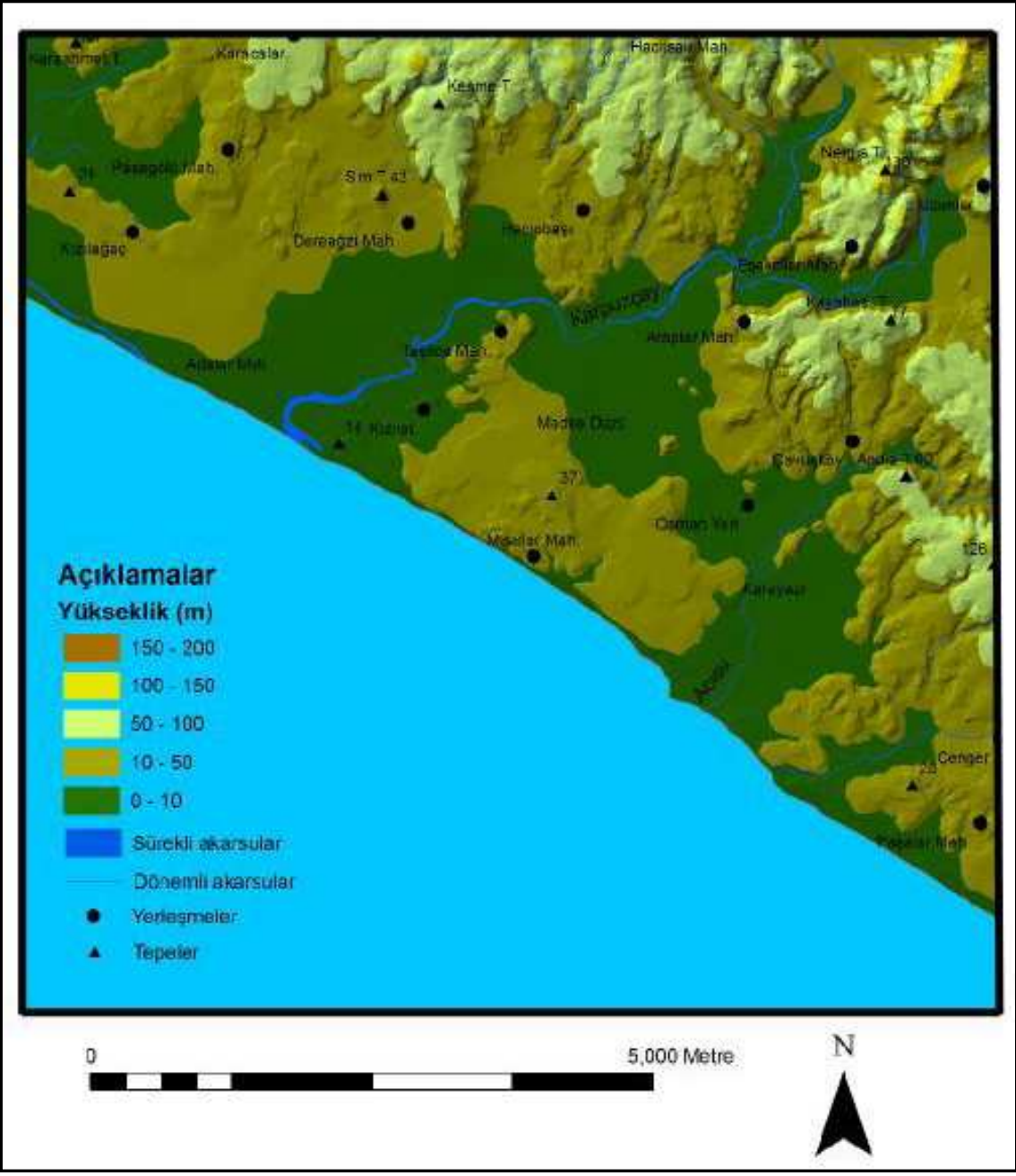

Şekil 2. Araştırma alanının fiziki haritası 
Anadolu'da Kuaterner boyunca meydana gelen deniz seviyesi oynamaları bugünkü kıyıların şekillenmesinde önemli bir paya sahiptir. Özzellikle kıyı ovalarının gelişiminde, deniz seviyesi oynamalarının etkisi büyüktür. Seviye değiş̧ikliklerine bağlı olarak, Akdeniz ve Ege kıyılarında yer alan pek çok tarihi liman kentinin doğal çevre koşulları tamamen değişmiştir.

Akdeniz kıyılarında, Hatay ve çevresindeki kıyı gelişimi Erol $(1969,1976)$ ve Pirazzoli, vd. (1991) tarafından, Alanya ve çevresindeki kıyı gelişimleri Kelletat ve Kayan (1983), Teke yöresindeki kıyı gelişimi Öner (1997 a) tarafindan incelenmiş, ancak bu alanlar arasında yer alan Karpuz Çay çevresi alüvyal jeomorfoloji açısından ele alınmamıştır. Bu çalışmada yeraltı verilerine dayalı bir inceleme benimsenmiş, özellikle arazide yapılacak sondaj çalışmaları ve bu sondajlardan elde edilen örneklerin analizi ile kıyı kesiminin Geç Pleistosen-Holosen'deki gelişiminin tarihlendirilmesi amaçlanmıştır.

\section{2.Önceki Çalış̧malar}

Erol (1969, 1976), Anadolu kıyılarının Holosendeki değişmelerini incelemiştir. Batı ve güneyde yer alan deltalarda pozitif deniz seviyesi değişmelerinin eseri olan boğulmuş vadilerin olduğunu ve Flandrien transgresyonundan sonra negatif bir değişmenin delili olarak Asi deltasında $+250,+140$ ve +80 santimetrelerde kalker içinde erime oyukları bulunduğunu tespit etmiştir.

Kayan (1988) Geç Holosen'de Batı Anadolu kıyılarında deniz seviyesi değişiklikleri konulu çalışmasında, delta ovalarının jeomorfolojik gelişimini ele almıştır. Erken Holosen'in post glasyal transgresyonu ile karakterize edildiğini, Orta Holosen'de deniz seviyesinin bugünkü seviyeye ulaştığını ve bu dönemde yükselmenin sona erdiğini, Geç Holosen'de delta ovalarının taşkın ovası sedimanlarıyla kaplandığını belirtmiştir.

Kayan (1995,1997), Öner (1997c,d) Ege ve Akdeniz kıyılarında deniz seviyesi ve kıyı çizgisi değişmelerini ele aldıkları çalışmalarında Ege kıyılarında günümüzden 6000 yıl kadar önce denizin bugünkü seviyesine ulaşmasından sonra, ırmak ağzı körfezlerinin alüvyonlarla hızla dolması sonucu delta ovalarına dönüştükleri belirtilmektedir. Günümüzden 5000-3500 yıl önceki dönemde deniz seviyesinin $2 \mathrm{~m}$ alçaldığı, milat yıllarına kadar tekrar bugünkü seviyeye yükseldiği saptanmıştır.

Pirazzoli (2005) Geç Holosen'de Akdeniz havzasında 8 farklı bölgede deniz seviyesi oynamalarını incelemiş, günümüzden 6000 yıl önce deniz seviyesi yükseliminin sona erdiğini belirtmiştir.

\section{Materyal ve Yöntem}

Çalışmada, öncelikle ilgili alanın 1/25.000 ölçekli topografya haritaları ve 1/35.000 ölçekli hava fotoğrafları değerlendirilerek sondaj noktaları belirlenmiştir. Sondaj noktalarının koordinatları GPS ile saptanmıştır. Kullanılan GPS'in (Magellan 315) hassasiyetinin düşük olmasından dolayı sondaj noktalarının yükseklik değerleri nivo ile de ölçülmüştür. Sondaj çalışmaları yanında yüzeysel jeomorfoloji incelemeleri de gerçekleştirilmiştir.

Motorlu sondaj aleti ile 3,5-21 m derinliklerde 17 adet sondaj yapılmışırı (Foto 2; Çizelge 1). Sondajlardan elde edilen bulgular arazide ve daha sonra laboratuar ortamında değerlendirilmiş, alınan örneklerin elek ve hidrometre yöntemleri ile analizleri yapılmış, tane boyutları belirlenmiştir. Organik kavkı içeren örneklerin $\mathrm{C}^{14}$ yöntemiyle tarihlendirilmesi Miami'deki (ABD) Beta Analitic firması tarafından yapılmıştır. Analiz sonuçları değerlendirilerek sondaj noktalarına ait kesitler elde edilmiştir. Bu kesitlerden yararlanılarak sahada farklı dönemlere ait 6 gelişim aşaması ortaya konulmuştur. 


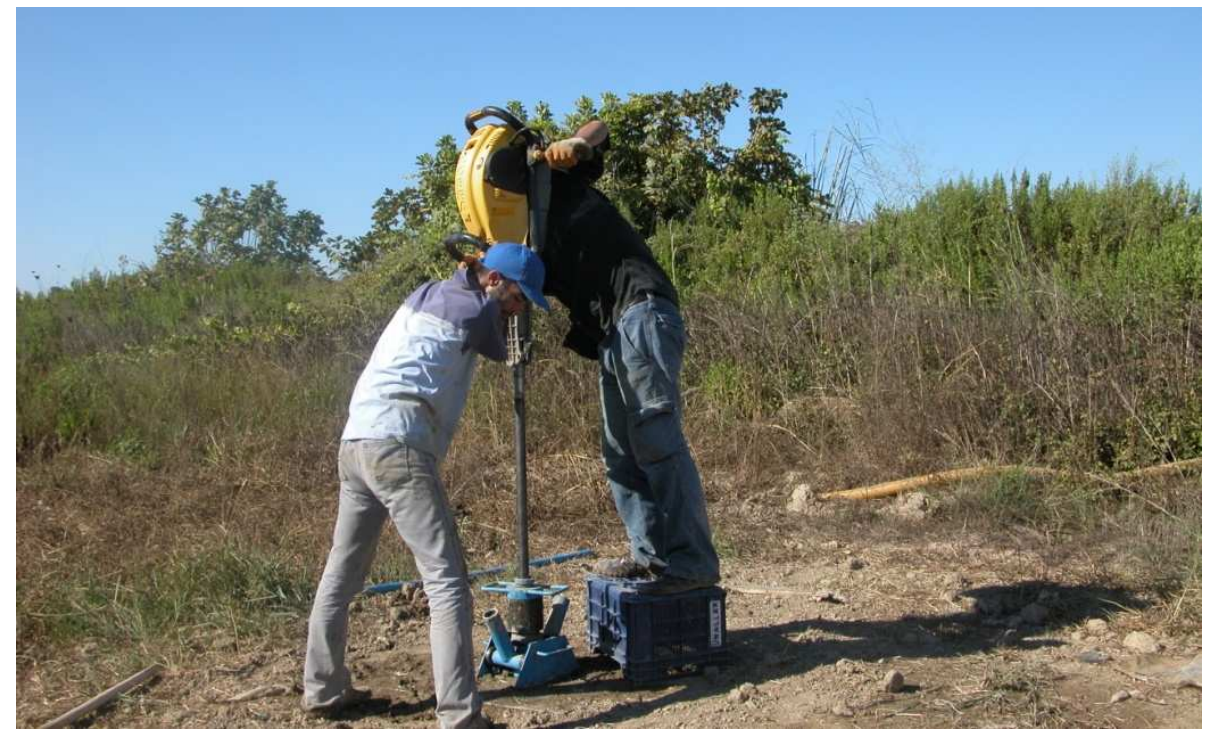

Foto 2. Sondaj çalışmaları Cobra Mk1 ile yapılmıştır.

Çizelge 1. Sondaj noktalarının yükseklik, derinlik ve deniz seviyesine göre durumları.

$\begin{array}{cccc}\text { Sondaj No } & \text { Yükseklik }(\mathrm{m}) & \text { Sondaj Derinliği }(\mathrm{m}) & \begin{array}{c}\text { Bugünkü deniz seviyesine } \\ \text { göre durum }(\mathrm{m})\end{array} \\ 04 / 1 & 9,30 & 12,30 & -3,00 \\ 04 / 2 & 5,00 & 12,70 & -7,70 \\ 04 / 3 & 5,00 & 6,70 & -1,70 \\ 04 / 4 & 10,00 & 5,70 & 4,30 \\ 04 / 5 & 5,00 & 10,70 & -5,70 \\ 04 / 6 & 5,40 & 9,70 & -4,30 \\ 04 / 7 & 5,00 & 5,30 & -0,30 \\ 04 / 8 & 9,00 & 3,50 & 5,50 \\ 04 / 9 & 8,00 & 3,50 & 4,50 \\ 04 / 10 & 3,30 & 14,00 & -10,70 \\ 05 / 1 & 5,00 & 21.00 & -16,00 \\ 05 / 2 & 10,30 & 6,60 & 3,70 \\ 05 / 3 & 9,30 & 6,50 & 2,80 \\ 05 / 4 & 9,00 & 5,30 & 3,70 \\ 05 / 5 & 8,00 & 7,60 & 0,40 \\ 05 / 6 & 4,20 & 4,30 & -0,10 \\ 05 / 7 & 7,30 & 18,60 & -11,30\end{array}$

\section{Karpuz Çay Deltası ve Yakın Çevresinin Jeolojik Özellikleri}

Çalışma alanı genel olarak Antalya Neojen havzası içerisinde yer almaktadır. Antalya Neojen Havzası, birbirinden bağımsız olarak gelişen Beydağları Miosen havzası, Antalya Miosen havzası ve tümüyle diğerlerinden bağımsız olarak gelişen Antalya Üst Miosen-Pliosen havzası ile temsil edilir ( Akay vd.1985a,b).

Çalışma alanımız Antalya Miosen ve Antalya Üst Miosen-Pliosen havzalarında yer almaktadır. Antalya Miosen havzası içerisinde kireçtaşı, killi kireçtaşı-breşik kireçtaş1 ardalanmasından oluşan Geceleme Formasyonu, şeyl-kumtaşı-çakıltaşından oluşan Karpuz Çay Formasyonu yer almaktadır. Prodelta ortamını yansıtan Geceleme, alan içerisinde en dar yayılıma sahip formasyondur.

Karpuz Çay, çalışma alanında en geniş alan kaplayan formasyondur. Delta özelliği taşıyan Karpuz Çay Formasyonu, ince-orta-kalın tabakalı gri, kirli sarı, yeşil, bej, krem renklerde kumtaşı, kiltaşı ve silt taşlarından oluşmaktadır (Glover ve Robertson 1998).

Antalya Üst Miosen-Pliosen havzası içerisinde ise, Messiniyen yaşında çakıltaş1kumtaşından oluşan Eskiköy Formasyonu, Alt Üst Pliosen yaşında killi kireçtaşı-kumtaşı, 
şeylden oluşan Yenimahalle Formasyonu yer almaktadır (Akay vd 1985a,b). Eskiköy Formasyonu, Karpuz Çay Formasyonu üzerine aşınımlı uyumsuzlukla gelmektedir. Formasyonun tortulanma özellikleri kıyı yakınındaki alüvyal yelpaze ortamını yansıtmaktadır.

Çalışma alanında Karpuz Çay'ın batısındaki sırtlar, Yenimahalle Formasyonuna ait kayaçlardan oluşmaktadır. Yenimahalle Formasyonunu oluşturan unsurlar dalga tabanı altında bir körfezde çökelmiştir.

Pleistosen yaşı Belkıs çakıltaşı Antalya Miosen havzasının güneyinde aşağı yukarı deniz kenarı boyunca bir uçtan diğer uca kadar uzanmaktadır. Bunların dağılımları incelendiğinde, bugünkü akarsuların eski birikintileri olduğu kolayca anlaşılır. Birim, yaklaşık 0-20 m kalınlıkta olup, Side-Manavgat yöresinde denizle örtülüdür (Şekil 3).

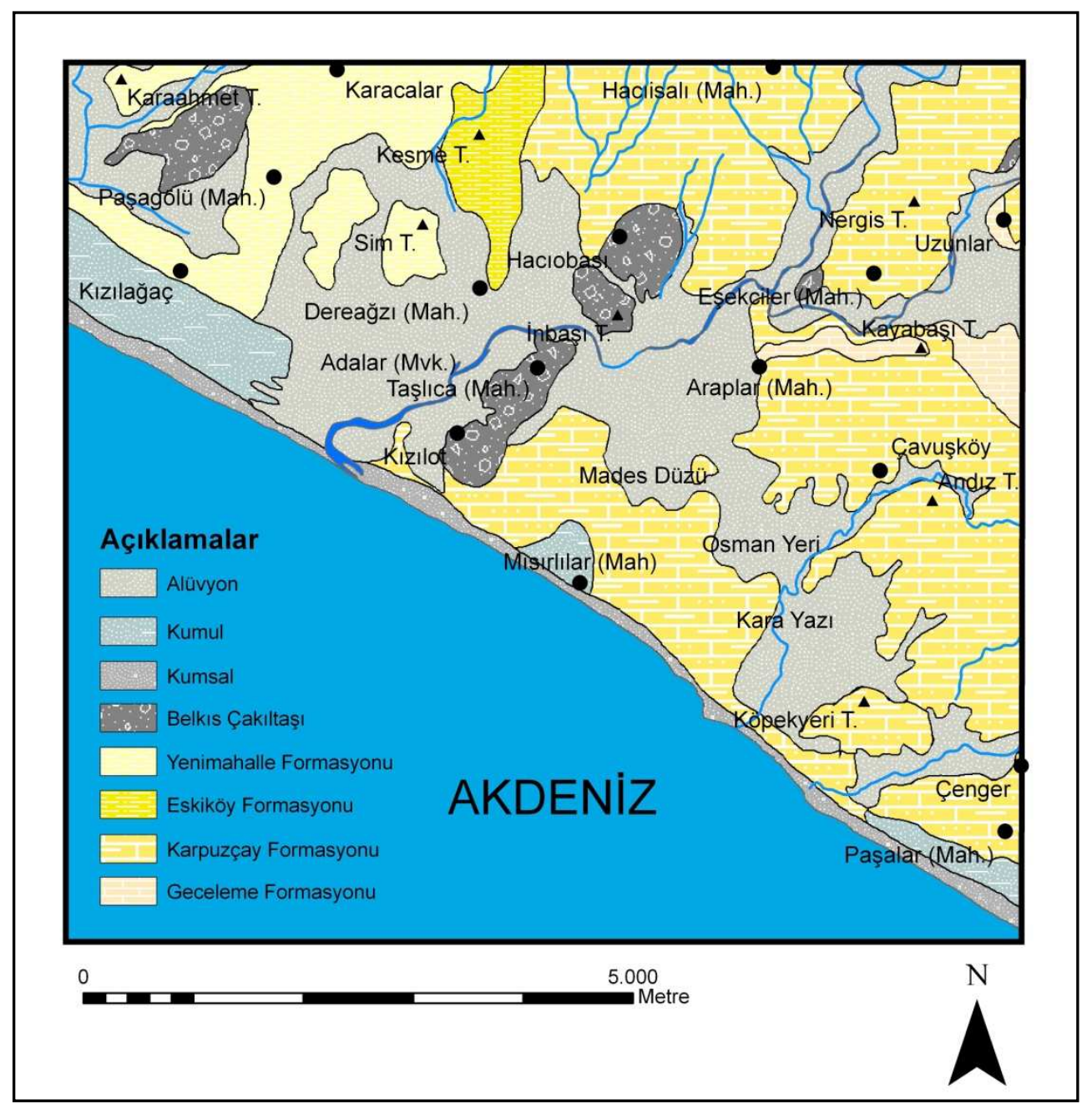

Şekil 3. Araştırma alanının jeoloji haritası (Akay ve Uysal 1985'den alınmıştır)

\section{Karpuz Çay Așağı Kesiminin Jeomorfolojik Özellikleri}

Çalışma alanında jeomorfolojik birimler genel olarak Karpuz Çay ve Yenimahalle Formasyonları üzerinde gelişmiştir. Bunlardan Karpuz Çay Miosen, Yenimahalle Formasyonu Pliosen yaşlıdır. Batı Toroslar kıvrım kuşağının güney kesiminde kalan çalışma alanında denizin çekilmesi Geç Pliosen'de gerçekleşmiştir. Bu nedenle yöredeki en yaşlı morfolojik birimler Geç Pliosen-Enalt Pleistosen yaşlı aşınım yüzeyleridir. Yükseltileri 100-120 metreler 
civarında olan bu yüzey parçaları çalışma alanının kuzeyinde yer almaktadır. Bu yüzeyler \%25 eğimle denize doğru uzanmaktadır. Yörede görülen Pleistosen yaşlı Belkıs konglomeraları, bunların korelan depolarıdır. Bu aşınım yüzeyleri genelde eğimi \% 20'yi geçen yamaçlarla diğer birimlerden belirgin şekilde ayrılmaktadır.

Kuzeydeki aşınım yüzeylerine yaslanan kesimlerde, Pleistosen'de oluşmuş ova ve vadi tabanları tektonik-östatik deniz seviyesi değişmelerine bağlı olarak 4 basamak halinde seki düzlüklerine dönüşmüştür. Bu basamaklar 70-80, 40-50, 20-30 ve 10 metre yüksekliğinde bulunmaktadır (Foto 3-4). Litoloji farklılığına bağlı olarak seki yüzeylerinin eğimleri \%2-10 arasında değişmektedir.

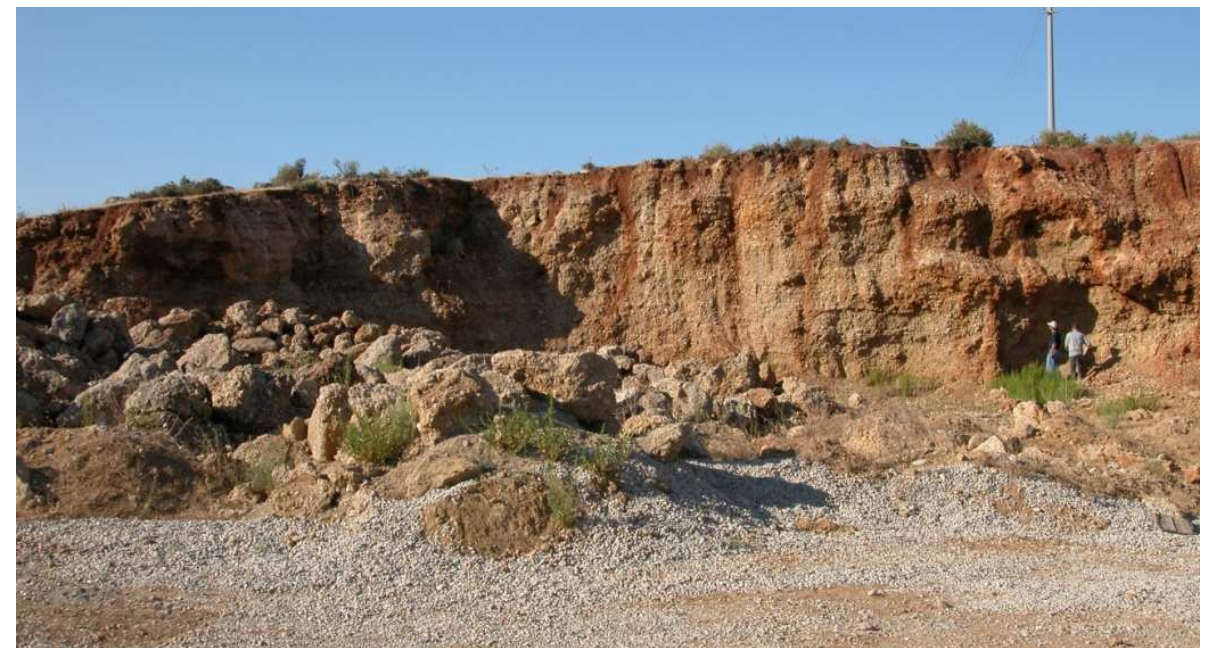

Foto 3. Misırlılar mahallesinin kuzeybatısındaki 20 metre sekisi

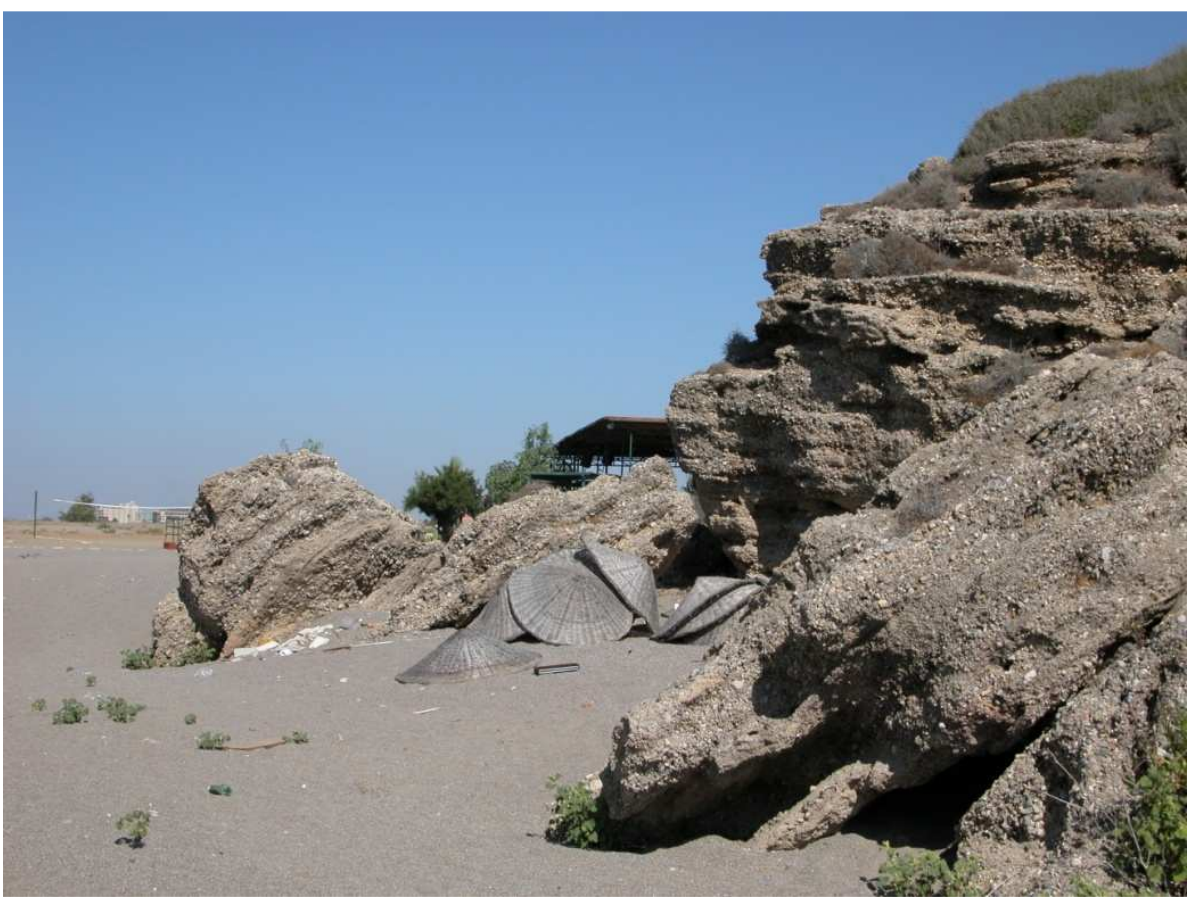

Foto 4. Misırlılar mahallesi güneyindeki 10 metre sekisine ait depolar

Çalışma alanındaki yüksek ve engebeli kesimleri oluşturan aşınım yüzeyleriyle aşağı kesimlerde yer alan sekiler, akarsularla yer yer derin bir şekilde yarılmıştır. Akarsular, yukarı 
kesimlerde genellikle tabansız dik yamaçı vadilerde, aşağı kesimlerde ise delta düzlüklerindeki nispeten geniş yataklarında akmaktadır. Karpuz Çay ve Acısu'yun taşıdığı alüvyonlar yörede Kızılot adı verilen delta ovasını oluşturmuştur. Karpuz Çay'ın ağız kesimindeki lagün ile deniz arasındaki bağlantı, akarsuyun taşıdığı su miktarına göre açılıp kapanabilmektedir (Foto 5).

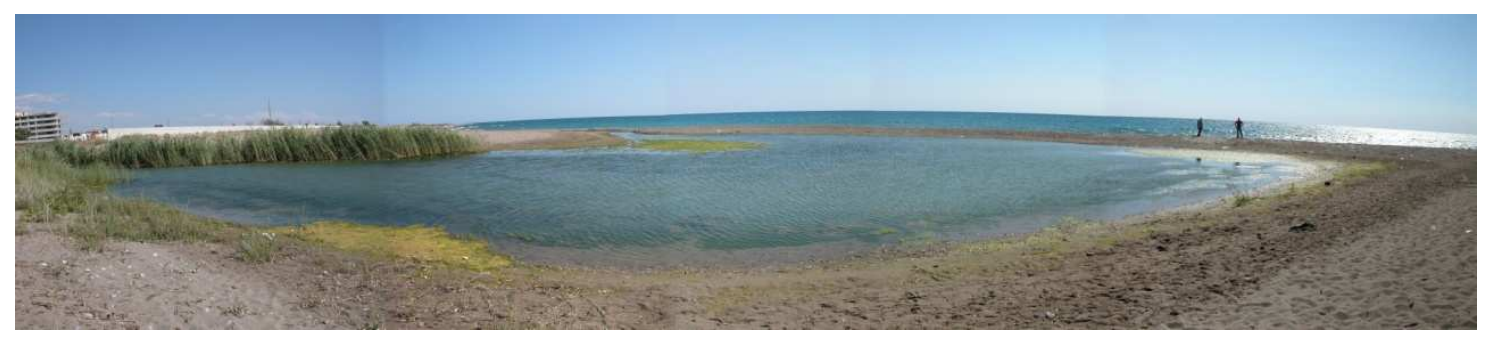

Foto 5. Karpuz Çay’ın ağız kesimindeki lagün ve doğuya yönelmiş kıyı kordonu

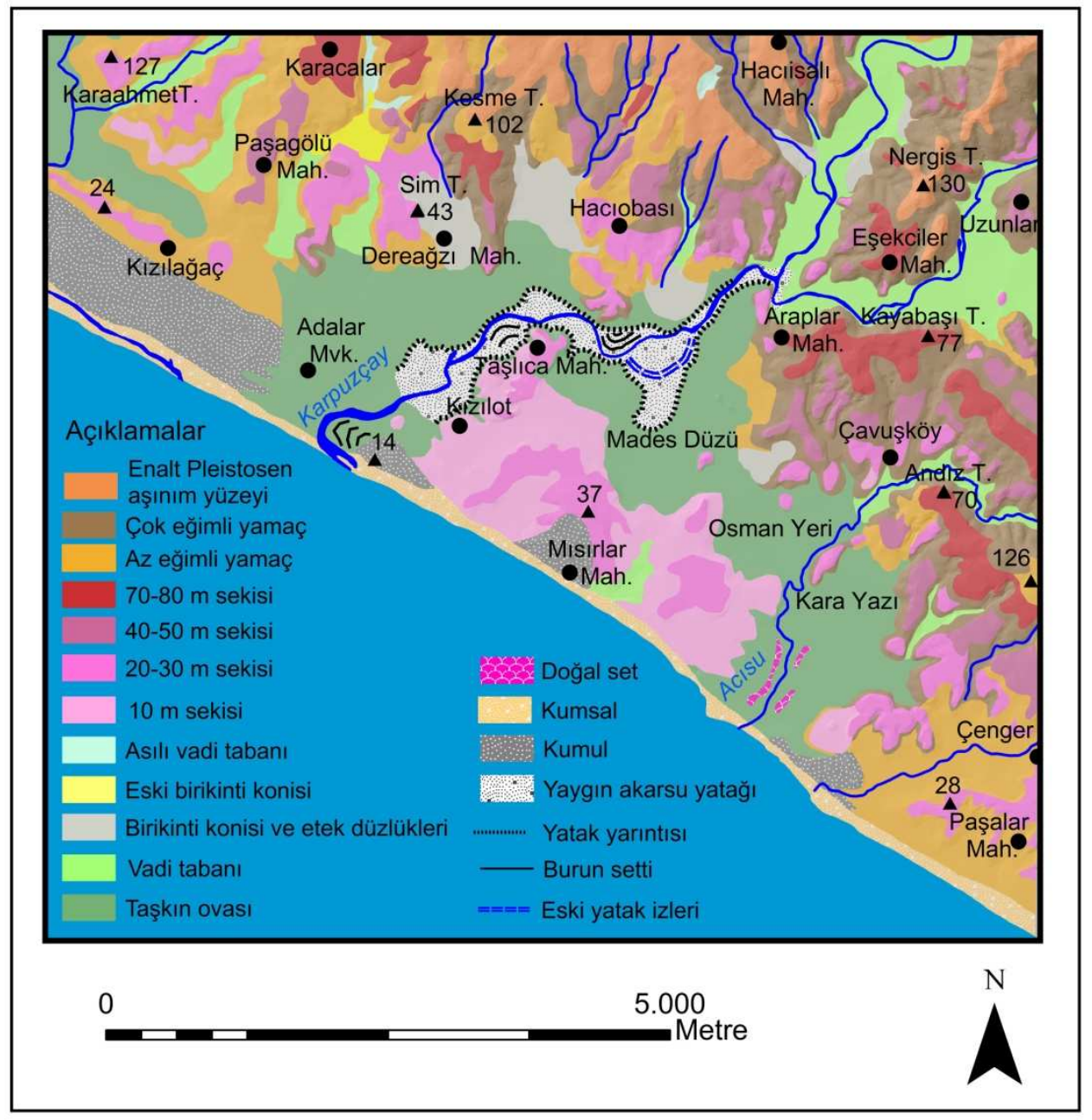

Şekil 4. Araştırma alanının jeomorfoloji haritası

Küçük bir havzaya sahip olan Acısu, Karpuz Çay’dan daha farklı bir gelişim izlemiştir. Günümüzde de küçük bir akarsu görünümünde olan Acısu'yun ağzındaki kıyı 
kordonunun gerisinde bir lagün gelişmiştir (Foto 6). Hava ve uydu fotoğraflarından izlenen eski yatak izleri, terk edilmiş bir delta lobunun ve doğal set depolarının bulunması, akarsuyun sık sık yatak değiştirdiğini göstermektedir. Bu birimlerin yoğun tarımsal faaliyetlere rağmen hava ve uydu fotoğraflarında belirgin şekilde görülmeleri, günümüzden 2000 yıl önce Acısu'yun ağzında bir bataklığın olması, belirtilen değişimlerin Milat yıllarından sonra meydana geldiğini ortaya koymaktadır (Şekil 4).

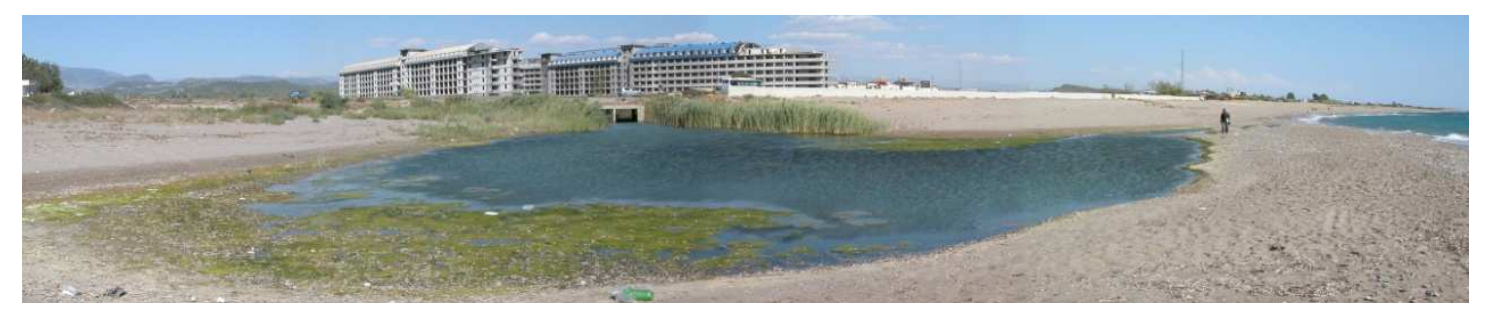

Foto 6. Acısu'yun ağız kesimi ve kıyı kordonu

Çalışma alanında, kıyı şeridini çevresel koşullara bağlı olarak zaman zaman daralıp genişleyen bir kumsal oluşturmaktadır. Kumsalı oluşturan ince kumlar, rüzgarlarla iç kesimlere doğru taşınmış ve yer yer yükseltisi 5-10 metrelere ulaşan kumulları oluşturmuştur (Foto 7). Bu kumullar, 10 metre sekisinin yamaçlarına yaslanmış durumdadır. Ayrıca Akdeniz kıyılarının pek çok yerinde olduğu gibi çalışma alanında da kıyının bazı kesimlerinde yalıtaşları görülmektedir.

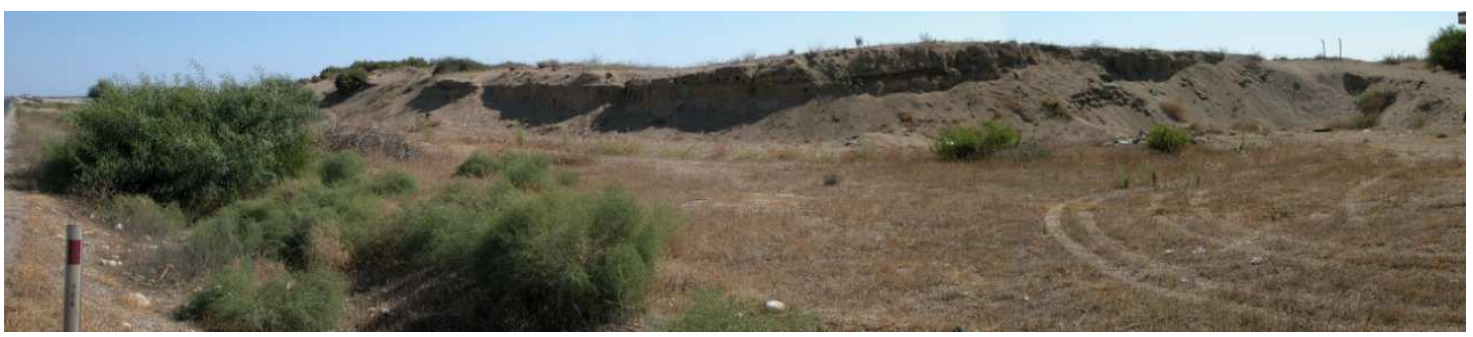

Foto 7. Acısu'yun ağız kısmı yakınındaki kumullar

\section{Analiz ve Bulgular}

Çalışma alanında yapılan 17 sondajın 5'i Karpuz Çay'ın batısında, 7'si doğusunda, 5'i de Acısu civarında gerçekleştirilmiştir. Sondajlardan alınan örnekler arazide ve laboratuar ortamında incelenmiştir. Bu örneklerden 151 adet sedimantolojik analiz yapılmıştır. Böylece her bir sondaj içindeki farklı tortulanma ortamları birbirinden ayrılmıştır.

Örneklerden, organik materyal içeren 10 adedi $\mathrm{C}^{14}$ yöntemiyle tarihlendirilmiş, elde edilen analiz sonuçları değerlendirilerek Karpuz Çay vadisi boyunca GB-KD, Acısu vadisi boyunca GB-KD ve Karpuz Çay-Acısu arasında KB-GD doğrultusunda kesitler oluşturulmuştur (Şekil 5).

Elde edilen bulgular ve sedimantolojik analiz sonuçlarına göre, alüvyal alanda farklı özelliklere sahip 6 birim belirlenmiştir. Bu birimler; 1-İri ve küçük çakıllı akarsu deposu, 2Sarımsı kahverengimsi kum bantlı az kumlu killi depolar, 3- Kil ağırlıklı taşkın depoları, 4Bataklık, 5-Kumul ve kumsal, 6-Güncel akarsu ve birikinti konisi depolarıdır.

Elde edilen bulgulara göre her bir sondajda genellikle iki-üç farklı ortam kesilmektedir. Kıyıdan uzak kesimlerde genellikle taşkın ovası ve bataklık materyalleri, kıyı yakınlarında ise taşkın ovası, bataklık ve denizel ortamlar görülmektedir (Foto 8-9). 04/2, 
04/6 ile 05/1 numaralı sondajlar kıyı çizgisinin belirlenmesinde önemli ipuçları sağlamıştır. 04/10 04/7, 04/6, 05/1 numaralı sondajda belirlenen denizel depoların görüldüğü seviyelerin karşılığında, daha iç kesimde ve aynı hat üzerinde yer alan ve 04/2 numaralı sondajda karasal depolara rastlanılmıştır. $\mathrm{Bu}$ bulgular, Holosen transgresyonunun sınırını ortaya koyan kanıtlardır. En derin seviyeye inilen 2005/1 numaralı sondaj, Holosen transgresyonu öncesi temele ulaşması ve yukarıda belirtilen 6 farklı ortamdan beşini kesmesi bakımından önemlidir.

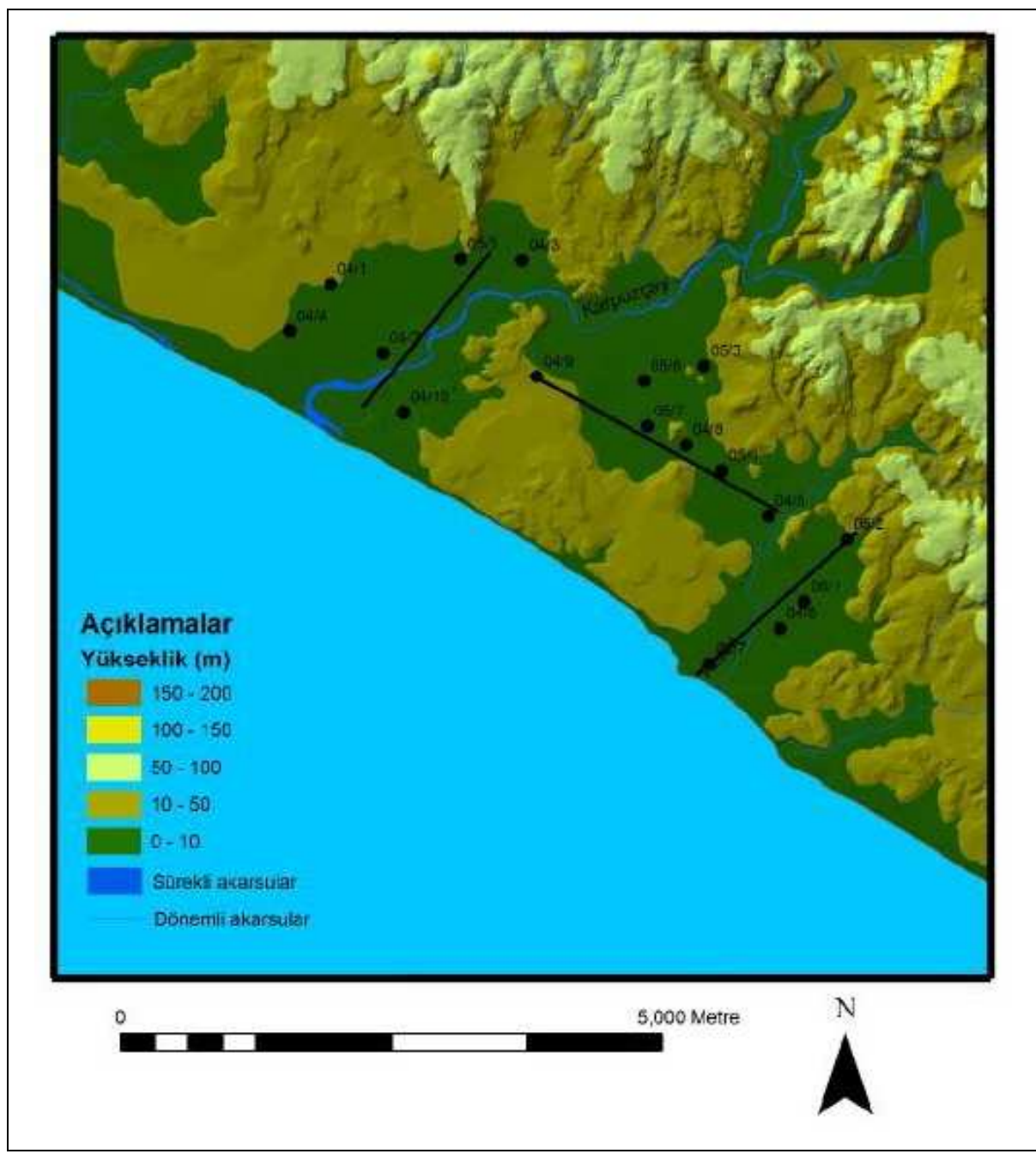

Şekil 5. Sondaj noktaları ve kesit hatları

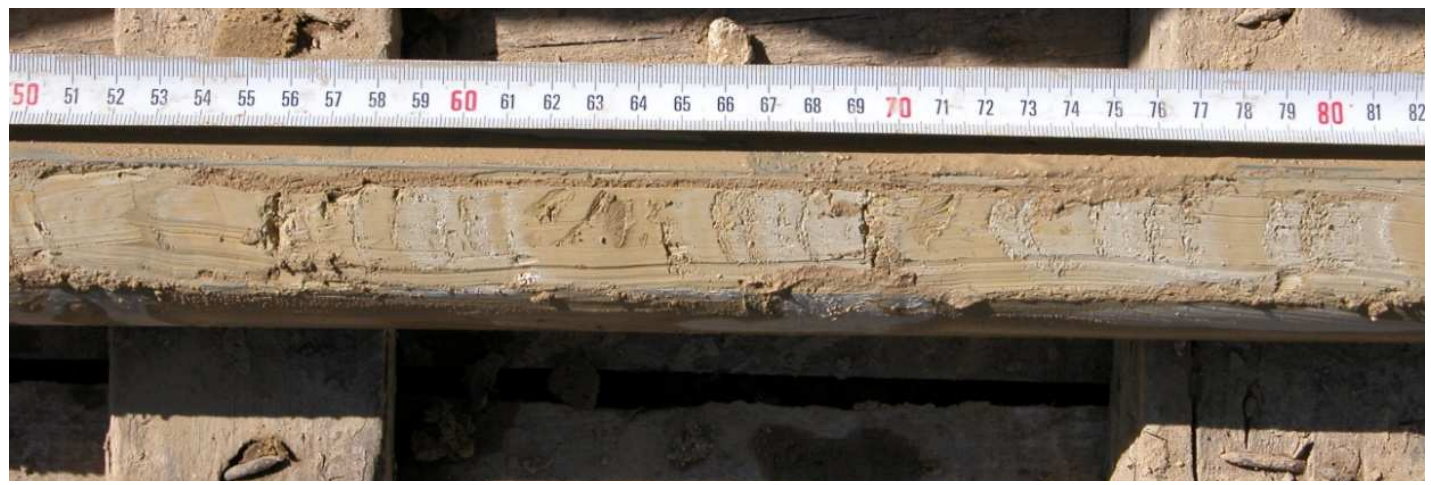

Foto 8. Mades Düzünde 05/07 nolu sondajda 5.60-5.80 metreler arasından alınmış taşkın ovası materyali. 


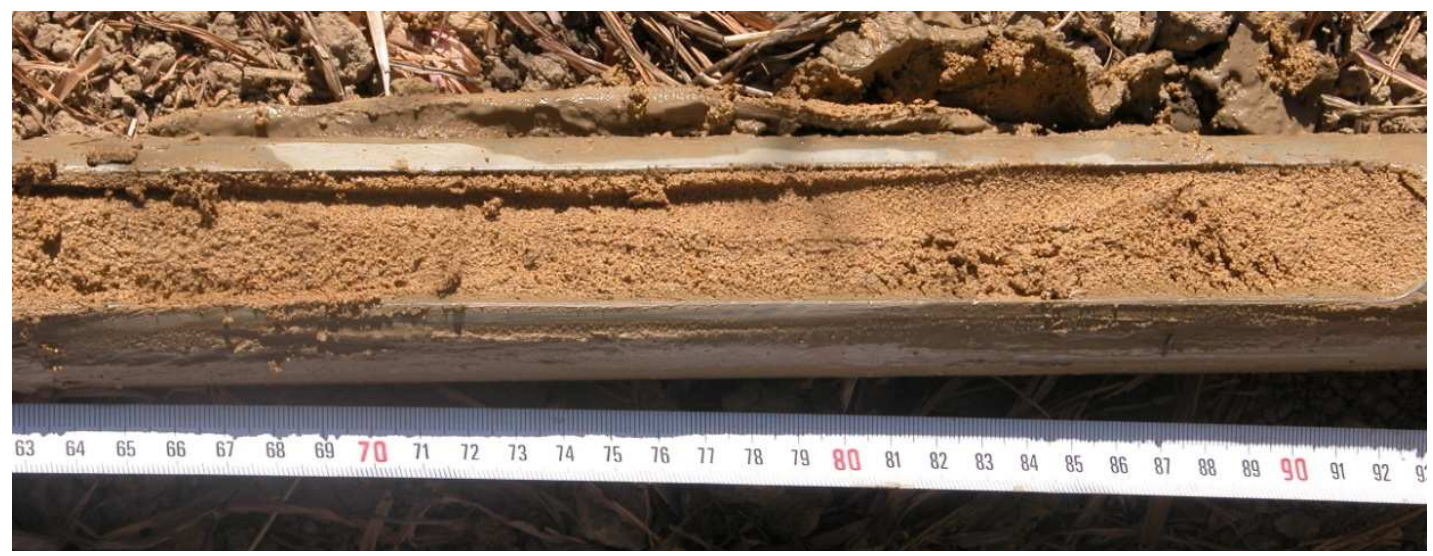

Foto 9. Kızılot'un batısında 04/10 nolu sondajda 6.70-6.90 metreler seviyesinden alınmış denizel kum örneği

Sondajlardan elde edilen örneklerdeki makro fosillerin incelenmesinde Bivalvia'lardan Cardium edule ve Gastropoda'lardan Cerithidea insulaemaris, Tegula pulliga, Gyraulus intermixtus ve Turritella terebra türleri tanımlanmıştır (Foto 10). Bunlar, özellikle Geç Kuaterner (Holosen) zaman aralığından günümüze kadar gelen türlerdir. Bu türlerin ekolojik özellikleri dikkate alındığında, bölgenin sığ denizel etki altında kaldığı, zaman zaman acısu ve tatlı su özelliğinde geliştiği anlaşılmaktadır (Makro fosillerin paleontolojik analizi Ankara Üniversitesi Mühendislik Fakültesi Jeoloji Mühendisliği Bölümünde yapılmıştır).

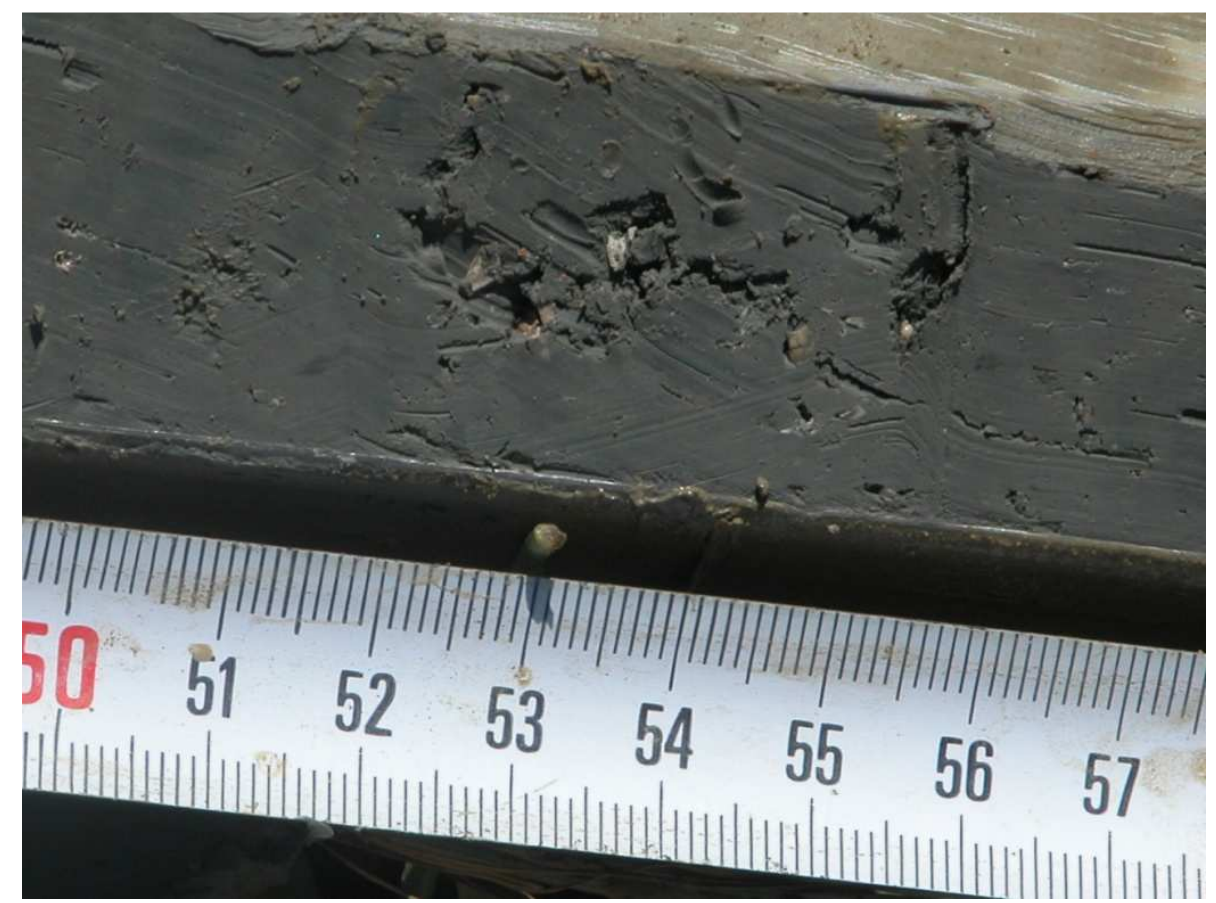

Foto 10. Karayazı mevkiinde 04/06 nolu sondajda 5.50 metreden alınan, içinde gastropoda kavkılarının bulunduğu bataklık deposuna ait örnek. 


\section{Karpuz Çay Aşağı Kesiminde Geç Pleistosen-Holosen'deki Doğal Ortam Özellikleri ve Gelişim Aşamaları}

Son Buzul Döneminin bitimine doğru (günümüzden 21.500 yıl kadar önce) deniz seviyesi -120 metrelerdeydi (Perissoratis, Conispoliatis 2003). Post Glasyal dönemde buzulların erimesiyle birlikte deniz seviyesi de yükselmeye başlamıştır. Günümüzden 11.500 y1l önce -60 metreye, 8000 yıl önce -15 metreye, 6.000 yıl önce de 0 metreye ulaşmışıtır (Perissoratis, Conispoliatis 2003, Pirazzoli,2005, Kayan, 1997, Öner, 1997) Bununla birlikte 10000-8000 y1l önce deniz seviyesinin -40,-30 metrelerde olduğunu belirten çalışmalar da bulunmaktadır (Kraft vd.1980, van Andel vd 1983). Sivan vd.(2001) tarihi yerleşmelere bağlı olarak yaptıkları çalışmada deniz seviyesinin G:Ö 8000'lerde deniz seviyesinin -13.5 ile -16.5 arasında değiştiğini, 7000'li yıllarda deniz seviyesinin yükselmesine rağmen seviyenin -7.0 metreden daha yüksek olmadığını belirtmişlerdir. Günümüzden 6000 yıl önce deniz seviyesinin -3 ile -4.5 metre arasında olduğunu, yaklaşık 3000 ile 2000 yıllarına kadar bugünkü seviyenin altında kaldığını tespit etmişlerdir. Bu gözlemlere göre de yöredeki tektonik sübsidansın $0.2 \mathrm{~mm} / \mathrm{y} ı$ civarında olduğunu saptamışlardır.

Çalışma alanında Karpuz Çay'ın ağız kesiminde 04/10K numaralı sondajda -2.20 , Karayazı mevkiinde $04 / 07 \mathrm{~K}$ numaralı sondajda $-0,3$ metre civarında denizel depolara girilmiştir. Bu sondajlardan 04/10K nolu sondajda -2.20 metreden alınan örneğin yaşı $C^{14}$ yaşlandırmasında $6960 \pm 40$ yıl olarak belirlenmiştir. Elde edilen bu sonuç ve değinilen diğer çalışmalara ait sonuçlar bölgenin farklı kesimlerinde tektoniğin çok etkili olduğunu ve kıyı bölgesinde belirgin bir sübsidansın varlığını göstermektedir.

Çalışma alanında 7 farklı jeomorfolojik gelişim aşaması belirlenmiştir. İlk iki gelişim aşaması (G.Ö 20.000 ve 11.500 y1l) yukarıda belirtilen genel deniz seviyesi değerleri ve deniz altı morfolojisini yansıtan eş derinlik (isobath) eğrilerinden yararlanılarak çizilmiştir. $\mathrm{Bu}$ dönemde, Karpuz Çay ile Acısu, gerisindeki yükseltilerden bol miktarda alüvyal malzeme getirerek, günümüz kıyı çizgisinden yaklaşık $3,5 \mathrm{~km}$ açıktaki denize dökülmekteydi. $\mathrm{Bu}$ akarsular taşıdıkları alüvyal malzemeler üzerinde menderesler çizerek büyük deltalar oluşturmuştur (Şekil 6).

Günümüzden 11.500 yıl önce buzul erimelerinin devam etmesine bağlı olarak deniz seviyesi -60 metrelere yükselmiştir (Perissoratis, Conispoliatis 2003). Bu dönemde de kıy1 gerisinden bol miktarda alüvyal malzeme taşınmasına rağmen, hızlı deniz seviyesi yükselmesi nedeniyle deniz bugünkü kıyı çizgisine göre, Karpuz Çayın ağız kesiminde $2.5 \mathrm{~km}$ kadar açıkta bulunmaktaydı (Şekil 6).

Çalışma alanındaki 3. gelişim aşaması günümüzden 7000 yıl öncesini yansıtmaktadır. 04/2, 04/10,04/7, 04/6 ve 05/1 numaralı sondajlar kıyı çizgisinin belirlenmesinde önemli ipuçları sağlamışlardır (Şekil 7a-b). 04/10 numaralı sondajda -2.00 ile -2.20 metreler arasında denizel ile lagüner ortamlar arasında geçiş saptanmıştır. Bu seviyeden alınan örneklerin yaşı $\mathrm{C}^{14}$ yaşlandırması sonucunda $\mathrm{G}: O ̈$ $6960 \pm 40$ çıkmıştır.Bu noktanın hemen kuzeyinde bulunan 04/2 numaralı sondajda ise aynı seviyelerde karasal killi siltli taşkın ovası depolarına rastlanmıştır. Bu durum G.Ö.7000'li yıllarda Acısu civarında denizin çok fazla içeriye sokulmadığını göstermektedir. Acısu civarında yapılan $04 / 6$ ve $05 / 1$ numaralı sondajlarda 1.20 metrelerde bataklık depolarına rastlanmıştır. 05/1 numaralı sondajda bataklık deposunun 3.90 metrede sona ermesi ve altında taşkın ovası materyaline rastlanması bu deponun sı̆ olduğunu ve denizin bu kesime kadar sokulmadığını göstermektedir. 05/1 numaralı sondaj Holosen transgresyonu öncesi temele ulaşması ve daha önce belirtilen 6 farklı ortamdan beşini kesmesi bakımından önemlidir.

Bu dönemde deniz Karpuz Çay’ın ağız kesiminde ve Kızılağaç civarında 400-800 metre, Karayazı mevkiinde ise $1.4 \mathrm{~km}$ kadar içeriye sokulmuştur (Şekil 6). Denizin çalışma alanının doğu kesiminde batıya göre fazla içeriye sokulamamasının nedeni, ana kayanın kıyıya 
daha yakın konumda bulunmasıdır. Bu dönemde, Osmanyeri mevkiinde bataklık araziler bulunmaktadır (Şekil 6)

Günümüzden 6000 yıl önce deniz en yüksek seviyesine ulaşmış, akarsu ağızları dışında günümüzdeki kıyı çizgisine benzer duruma gelmiştir. Bu dönem öncesinde deniz seviyesi azalan bir hızla da olsa (Bard vd.1990) yükselmeye devam etmiş,. fakat karasal dolguların daha hızlı ilerlemesiyle deniz iç kesimlere sokulamamıştır. Çalışma alanında 6000 y1l önce Acısu ve Karpuz Çay birbirinden küçük yapısal sirtlarla ayrılan havzalar durumundadır. Bu havzalardaki denizel depolardan çıkan Bivalvia (Cardium edule) türlerinin kabuk çiftlerinin kapalı durumda ve parçalanmamış olması, bunların otokton olduklarını göstermektedir. $\mathrm{Bu}$ fosilli denizel deponun üst yüzeyi hemen hemen bugünkü deniz seviyesinde bulunmaktadır.

Bu dönemde Mades Düzü ve Osmanyeri'nde yeni bataklıklar oluşmuştur. Bu ortamı yansıtan 04/5 numaralı sondajda $-1.20-1.30$ metreler arasından alınan örneklerin yaşı $\mathrm{C}^{14}$ tarihlendirmesinde $5850 \pm 40$ y1l olarak belirlenmiştir (Şekil 7c). 04/3 ve 05/5 numaralı sondajlarda iri akarsu çakılları ile kumlu çakı1lı depolara rastlanması, Karpuz Çay'ın örgülü bir drenaja sahip olduğunu ortaya koymaktadır. Karpuz Çay ve Acısu'yun taşıdığı alüvyonlar ve kumlar, akıntılar ve batıdan esen rüzgarların etkisiyle kıyı boyunca doğuya doğru sürüklenmiştir. Bu kumlar taşkın ovasından doğuya doğru uzanan kıyı oklarını ve kıyı kordonlarını oluşturmuş, kıyı kordonlarının gerisinde de lagünler gelişmiştir (Şekil 6).

Günümüzden 4000 yıl önce kıyı çizgisinde akarsuların ağız kesimleri dışında önemli bir değişiklik olmamış, Karpuz Çay ve Acısu'yun deltaları denize doğru ilerlemeye devam etmiştir (Şekil 6). Karpuz Çay ve Acısu'yun ağız kısmında geniş bir lagün bulunmaktadır. Sondajlardan elde edilen örnekler, sık sık ortam değişikliği olduğunu ortaya koymaktadır. Kaba kumlu kıyı tortulları ile siyahımsı gri renkli, organik katkı1ı, lagün depolarının sondajda birkaç defa kesilmesi ortam değişikliğinin en önemli göstergesidir

$\mathrm{Bu}$ dönemde karasal dolgular daha etkindir. Akarsuların taşıdığı bol malzeme nedeniyle bataklıklar küçülürken, Osmanyeri ile Mades düzünü ayıran alçak yapısal sırt karasal dolgularla örtülmüş ve bu iki havza birleşmiştir (Foto 11). 04/10 numaralı sondajda +1 metreden alınan örneğin $C^{14}$ analizinde buranın yaşının $4010 \pm 40$ olduğu saptanmıştır (Şekil 7a). Aynı sondajda -2.00 ile -2.20 metreler arasından alınan örneğin yaşının $6960 \pm 40$ olması buradaki tortulanma hızının $1.1 \mathrm{~mm} / \mathrm{y} ı 1$ olduğunu ortaya koymaktadır.

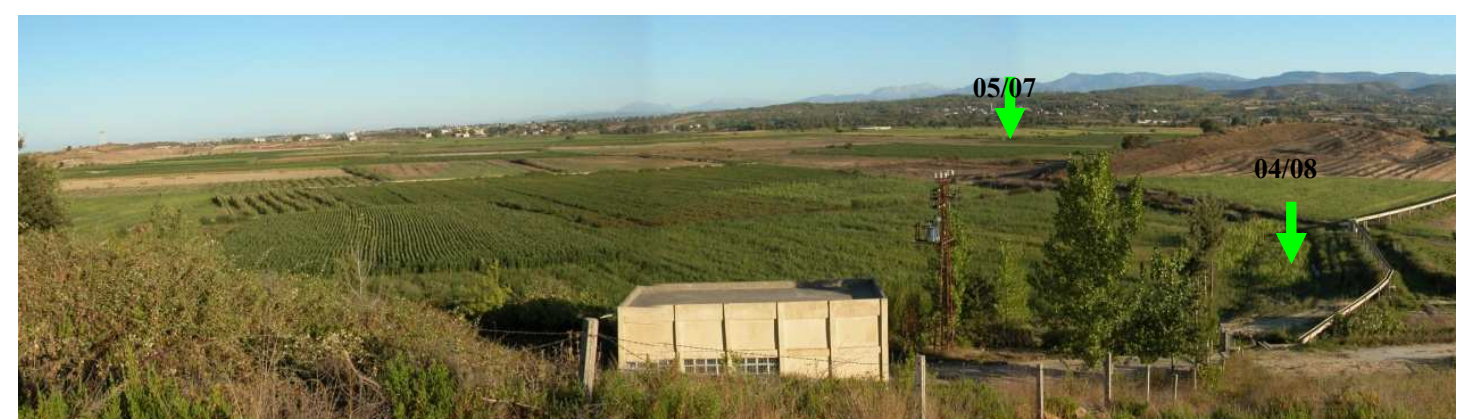

Foto 11. Osman Yeri ve Mades Düzünün güneyden görünüşü ve $05 / 7$ ile $04 / 8$ nolu sondaj noktaları

Günümüzden 2000 y1l öncesine gelindiğinde, bir önceki döneme göre önemli ortam değişiklikleri belirlenmiştir. Bu dönemde bataklık alanları iyice küçülerek kuruma aşamasına gelmiş̧tir. Akarsuların ağız kesimlerinde bulunan lagünler karasallaşarak ortadan kalkmışlardır. Sadece Karpuz Çay’ın ağız kesiminde, Kızılot civarındaki lagün küçük bir art bataklığa dönüşmüştür. Kıyı çizgisinde görülen belirgin durağanlaşma nedeniyle kıyı boyunca kumsallar gelişmeye başlamıştır (Şekil 6). 


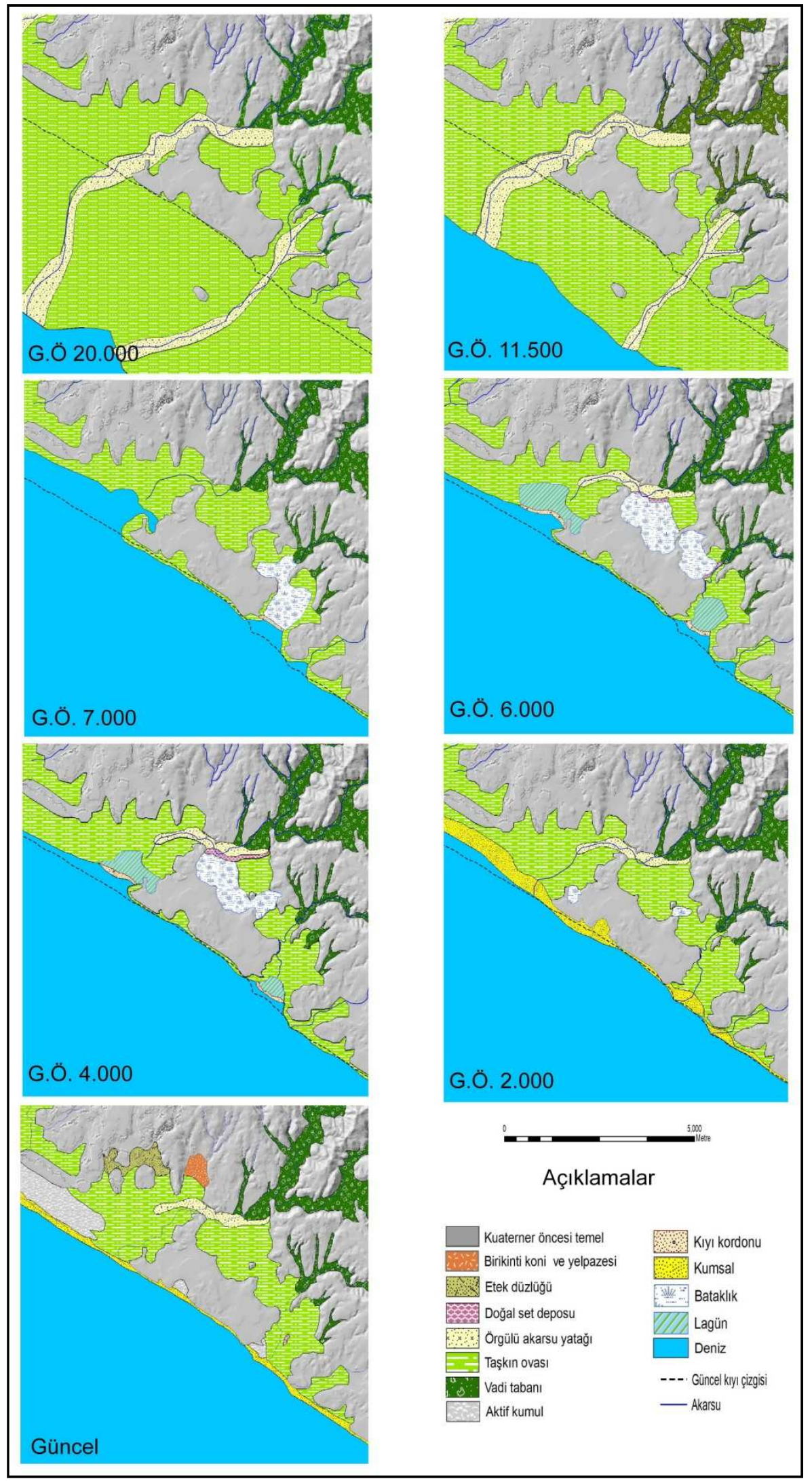

Şekil 6. Karpuz Çay deltasının gelişim aşamaları 


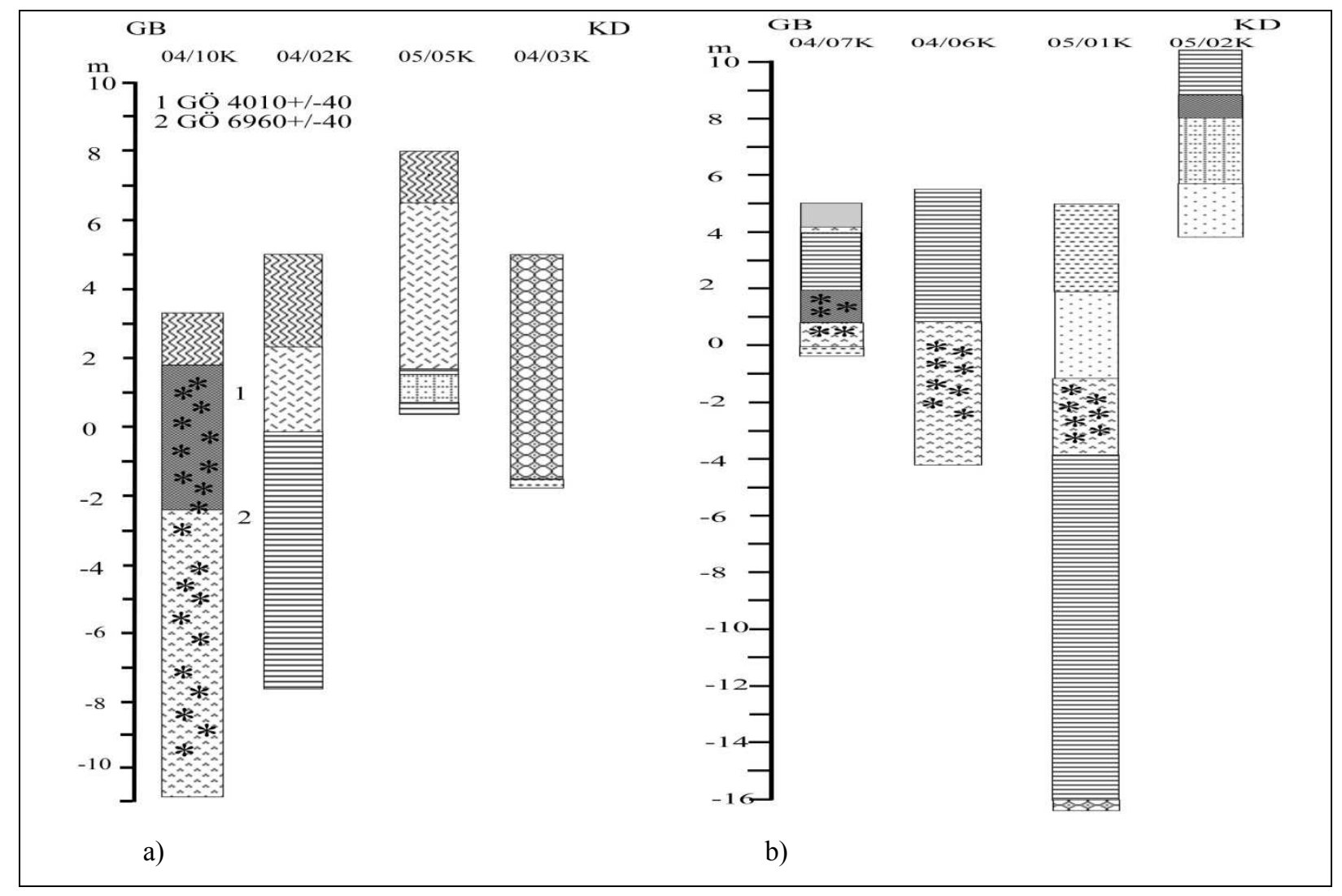




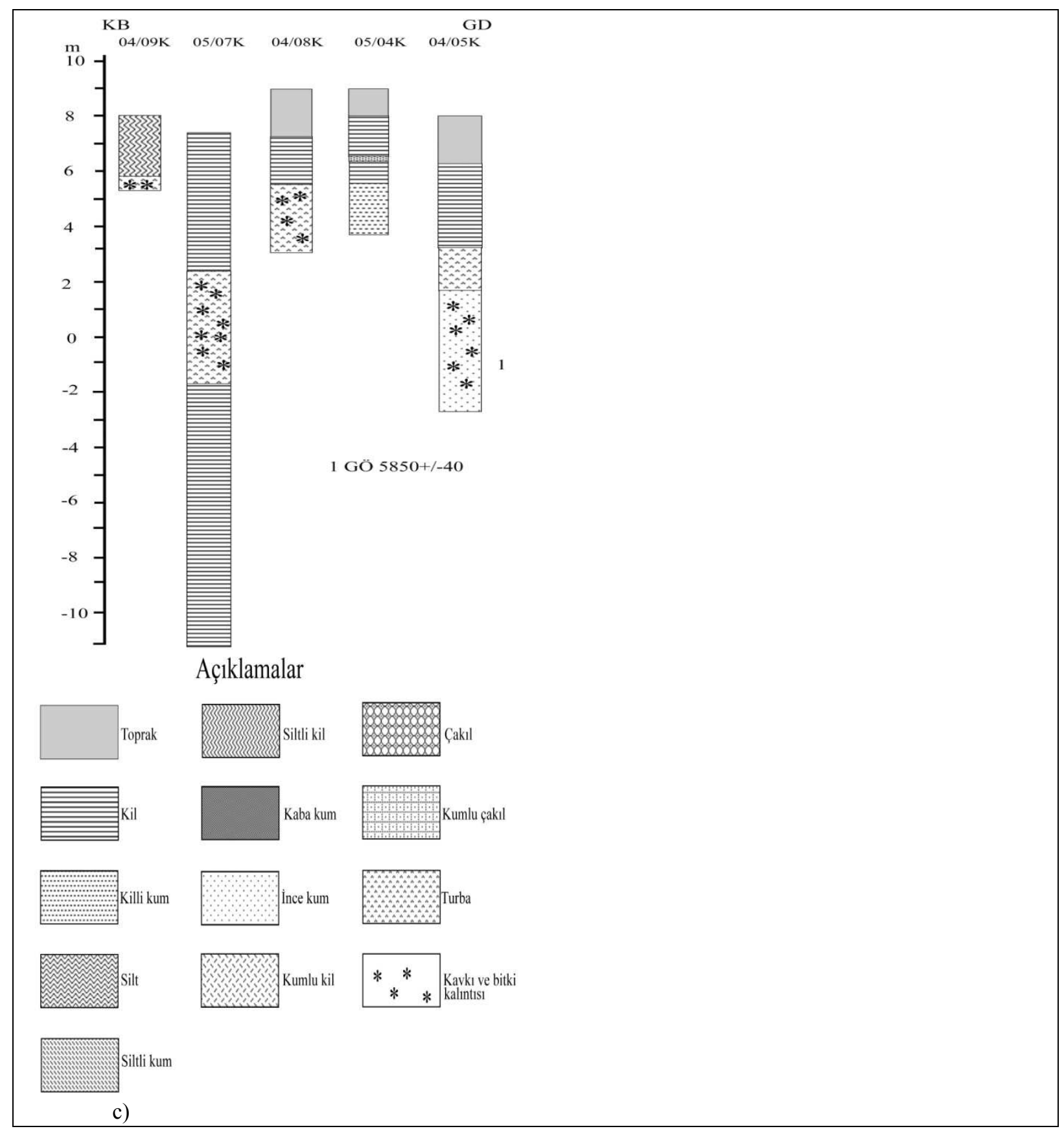

Şekil 7. Sondaj Kesitleri

Günümüze gelindiğinde, gerideki yamaçlardan sürekli karasal materyalin gelişine bağl1 olarak birikinti konileri genişlemiş ve yer yer birikinti yelpazelerine dönüşmüştür. Birikinti yelpazelerinin belirginleşmesinde, taşkın ovasının çok büyümesi ve taşkınların artık bu kesimlere ulaşamamasının etkisi olmuştur. Buna bağlı olarak birikinti yelpazelerinin üzeri taşkın depoları ile örtülememiştir.

Bu dönemde Dereağzı Mahallesi ve Hacıobası civarındaki birikinti yelpazesi ve etek düzlükleri gelişerek taşkın ovasının üzerini örtmüştür. Kızılağaç, Mısırlar Mahallesi ve Acısu'yun ağız kesiminde güncel kumullar gelişmiştir (Şekil 6) Acısu'yun ağzında, bazen kıyı 
oku bazen de kıyı kordonu durumunda olan alüvyal birikintiler güncel kıyıda da oluşumunu sürdürmektedir.

Karpuz Çay ve yakın çevresi günümüzde tektonik açıdan hareketliliğini sürdürmektedir. Kelletat ve Kayan (1983) Alanya batısında yaptıkları çalışmada 1550 yıl kadar önce Neotektonik bir olayla abrazyon platformlarında 0.5-1.3 metre yükselme saptamışlardır. Yıldız ve Demir (2002) Antalya'da deniz seviyesinin $7.93 \pm 0.98 \mathrm{~mm} / \mathrm{y} 1 \mathrm{l}$ yükseldiğini ortaya koymuşlardır. Bu yükselmenin $2.58 \pm 1.14 \mathrm{~mm} / \mathrm{y} 1$ lının östatik deniz seviyesi yükselmesi olduğunu $5.35 \pm 0.60 \mathrm{~mm} / \mathrm{y}$ 1lının ise tektonik sübsidansa bağlı olduğunu saptamışlardır. Bu durum Akdeniz kıyılarında zaman içinde kısa mesafeler boyunca tektonik karakterin değiştiğini göstermektedir.

\section{Sonuç}

Antalya körfezinin doğusunda, Karpuz Çay ve Acısu tarafından oluşturulan kıyı ovası, daha çok tepelik alanlarla çevrelenmiş alçak kıyı özelliğindedir. Ova bugünkü görünümünü Holosen'de özellikle son 6000 yıllık dönemde kazanmıştır. Geç Pleistosen ve Holosen boyunca meydana gelen çevresel değişikliklerin saptanması amacıyla sondajlar yapılmış, elde edilen sonuçlar ve arazi gözlemlerine dayanılarak sahanın alüvyal jeomorfolojisi ve jeomorfolojik gelişimi ortaya konmuştur.

Sondajlardan elde edilen bulgulara göre çizilen kesitlerde genellikle iki-üç farklı ortamın kesildiği anlaşılmaktadır. Kıyıdan uzak kesimlerde genellikle taşkın ovası ve bataklık materyalleri, kıyı yakınlarında ise taşkın ovası, bataklık ve denizel ortamlar görülmektedir. İncelenen kıyı ovası, zaman içinde bu üç ortamdaki değişikliklerle şekillenmiştir.

Ovayı kuzeyden çevreleyen tepelik alanlar genellikle şeyl, miltaşı, çamurtaşı, kumtaşı ve çakıltaşı litolojisindeki yaşlı kayaçlardan oluşmaktadır. Jeomorfolojik birimler genel olarak Karpuz Çay ve Yenimahalle formasyonları üzerinde gelişmiş̦tir. Bunlardan Karpuz Çay Miosen, Yenimahalle formasyonu Erken-Geç Pliosen yaşlıdır. Batı Toros Kıvrım Kuşağının güney kesiminde kalan çalışma alanında denizin çekilmesi Geç Pliosen'de gerçekleşmiştir.

$\mathrm{Bu}$ nedenle yöredeki en yaşlı morfolojik birimler Geç Pliosen-En Erken Pleistosen yaşlı aşınım yüzeyleridir. Kuzeydeki aşınım yüzeylerine yaslanan kesimlerde Pleistosen'de oluşmuş ova ve vadi tabanları tektonik-östatik deniz seviyesi değişmeleri nedeniyle kıyı çizgisinin güneye çekilmesi sonucu, yükseklikleri 10-80 metre arasında değişen sekilere dönüşmüş̧ür.

Kıyı ovasında, eski yatak izleri, kopmuş menderesler ve burun setti depoları başlıca flüvial birimlerdir. Bu birimlerin hava ve uydu fotoğraflarında belirgin şekilde görülmeleri ve yoğun tarımsal faaliyetlere rağmen silinmemiş olması, yatak değişimlerinin yeni olduğunu kanıtlamaktadır. Bu değişimlerin 2000 yıl öncesi ile günümüz arasında olduğu söylenebilir.

$\mathrm{Bu}$ bulgular 1şı̆̆ında, kıyı ovası oluşumu sırasındaki deniz seviyesi değişimlerinin gelişimi şöyle özetlenebilir: Son buzul döneminin bitimine doğru (günümüzden 20.000 yıl kadar önce) deniz seviyesi -120 metrelerdeydi. Bu nedenle o dönemdeki ova yüzeyi daha alçak bir seviyede, kıyı çizgisi de daha açıkta yer almaktaydı. Post Glasyal dönemde buzulların erimesiyle birlikte deniz seviyesi de yükselmeye başlamıştır. Günümüzden 11.500 y1l önce -60 metreye, 7000 yıl önce -2 metreye, 6.000 yıl önce de 0 metreye ulaşmıştır.

Çalışma alanında 7 farklı jeomorfolojik gelişim aşaması belirlenmiştir. 7000 yıl önce deniz, $400 \mathrm{~m}$ ile $1.4 \mathrm{~km}$ kadar içeriye sokulmuştur.

6000 yıl önce deniz en yüksek seviyesine ulaşmış, kıyı çizgisi, günümüzdekine benzer duruma gelmiştir. Bu dönemde deniz en yüksek seviyesine ulaşmasına rağmen karasal dolguların daha hızlı ilerlemesi nedeniyle iç kesimlere sokulamamıştır.

Günümüzden 4000 yıl önce kıyı çizgisinde akarsuların ağız kesimleri dışında önemli bir değişiklik olmamış, Karpuz Çay ve Acısu'yun deltaları denize doğru ilerlemeye devam etmiştir. Bu dönemde karasal dolgular morfolojik gelişimde daha etkin duruma geçmiştir. 
Günümüzden 2000 yıl öncesinde, bir önceki döneme göre önemli ortam değişiklikleri meydana gelmiştir. Bataklıklar küçülerek kuruma aşamasına gelmiş, akarsuların ağız kesimlerinde bulunan lagünler karasallaşarak ortadan kalkmışlardır.

Yörede tortulanma hızı akarsulara ve zamana bağlı olarak değişmiştir. $\mathrm{C}^{14}$ tarihlendirmelerine göre yöredeki tortulanma hızının $0.53 \mathrm{~mm} / \mathrm{y} 1 \mathrm{l}$ ile $1.7 \mathrm{~mm} / \mathrm{y}$ ll arasında değiştiği saptanmıştır.

Yakın zamanda tarım faaliyetlerine açılan kıyı ovasında kıyı kenar çizgisine ve güncel akarsu yatağına doğru yoğun şekilde bir insan etkinlikleri dikkati çekmektedir. Bu durum yörede giderek artan çevre sorunlarına neden olmaktadır. Antalya ile Alanya arasında kalan araştırma alanında turizm faaliyetleri artarak devam etmektedir. Özellikle turistik yapıların denize yakın kesimlerdeki eski lagün ve bataklık alanlarda yığıldığı görülmektedir. $\mathrm{Bu}$ alanlarda taban suyu yüksekliği ve gevşek dokulu malzemeler nedeniyle oluşacak sıvılaşma sonucunda binalarda oturma ve çarpılmalar olabilmektedir. Ayrıca, tesislerin akarsu ağızlarına yakın olmaları nedeniyle sivrisinek sorunu yaşanmaktadır. Bu durum çeşitli sağlık sorunlarına neden olabilmektedir.

Kıyıdaki kumullardan inşaat malzemesi olarak faydalanılmaktadır. $\mathrm{Bu}$ durum kıyı dinamiğini bozduğu gibi 3621 sayılı kıyı kanununun 6. maddesine de aykırıdır. Özellikle bitki örtüsünün tahrip edilmesi nedeniyle kıyı kumulları canlanarak yakın kesimlerdeki yerleşme ve tarım alanlarını tehdit etmeye başlamıştır.

\section{Referanslar}

Akay, E., Uysal, Ş., Poisson, A., Cravatte, C.F.P.J., Müler, C. (1985a) Antalya Neojen Havzasının Stratigrafisi. Türkiye Jeoloji Kurumu Bülteni 28, 105-119

Akay, E., Uysal, Ş. (1985b) Orta Torosların Batısındaki (Antalya) Neojen Çökellerinin Stratigrafisi, Sedimentolojisi ve Yapısal Jeolojisi. MTA Rap. No: 7799

Bard, E., Hamelin, B., Fairbanks, R.G., (1990) IJ-Th age obtained by mass spectrometry in corals from Barbados:sea level during the past 130.000 years. Nature 340, 456-458,

Erol, O. (1969) Anadolu Kıyılarının Holosendeki değişmeleri hakkında gözlemler A.Ü.D.T.C.F. Coğrafya Araştırmaları Derg., S:2, s:89-102, Ankara.

Erol, O.(1976) Quaternary shoreline changes on the Anatolian Coasts of the Aegean Sea and related problems. Bull.Soc.Geol.t.XVIII, n 2, p.459-468 \& Coll.intern.CNRS, Paris, n 244, p.263-272

Glover, C.P., Robertson, H.F. (1998) Role of regional extention and uplift in the Plio-Pleistocene evolution of the Aksu Basin, SW Turkey. Journal of the Geological Society, V:155, p:365-387.

Kayan, İ., (1988) Late Holocene Sea-Level Changes on the Western Anatolian Coast" Paleogography, Paleoclimatology, Paleoecology, 68, p:205-218, Elsevier Science Publishers B.V. Amsterdam.

Kayan, İ., (1995) Klaros Kazı alanında jeomorfolojik-jeoarkeolojik araştırmalar Ege Üniv, Ed. Fak., Ege Coğrafya Derg., S:8, s:1-24, İzmir.

Kayan, İ.,(1997 ) Türkiye'nin Ege ve Akdeniz kıyılarında deniz seviyesi ve kıyı çizgisi değişmeleri. Türkiye'nin Kıyı ve Deniz Alanları I. Ulusal Konferansı, Türkiye Kıyıları 97 Konferansı Bildiriler Kitabı; s:735-746

Kelletat, D., Kayan,İ. (1983) Alanya batısındaki kıyılarda ilk $C^{14}$ tarihlendirmelerinin ışı̆̆ında Geç Holosen tektonik hareketleri. TJK Bülteni, C:26, s:83-87

Kraft, J.C., Kayan, I., and Erol, O., (1980), Geomorphic reconstructions in the environs of ancient Troy: Science V. 209, p. 776-782.

Öner, E., (1997 a) Teke Yarımadası kıyılarında deniz seviyesi ve kıyı çizgisi değișmeleri’. Türkiye Kıyıları `97 (Türkiye'nin Kiyl ve Deniz Alanları 1.Ulusal Konferansı) Bildiriler Kitabl, s:723-733, Ankara.

Öner, E., (1997 c) Eşen Çayı Taşkın-Delta Ovasının jeomorfolojisi ve Antik Patara Limanı” Ege Üniv, Ed. Fak., Ege Coğrafya Derg., S:9, s:89-130, İzmir.

Öner, E., (1997 d) Finike Ovasının Alüvyal Jeomorfolojisi ve Antik Limyra Kenti” Ege Üniv, Ed. Fak., Ege Coğrafya Derg., S:9, s:131-157, İzmir.

Pirazzoli, P.A., Laborel, J., Saliege,J.F., Erol, O., Kayan,İ., Person,A. (1991) Holocene raised shorelines on the Hatay coasts (Turkey):Paleoecological and tectonic implications.Marine Geology. 96, p:295-311, Elsevier Science Publishers B.V. Amsterdam

Pirazzoli, P.A.(2005) A review of possible eustatic, isostatic and tectonic contributions in eight late-Holocene relative sea-level histories from the Mediterranean area. Quaternary Science Reviews 24, p:1989-2001

Perissoratis, C.N. Conispoliatis, N., (2003) The impacts of sea-level changes during latest Pleistocene and Holocene times on the morphology of the Ionian and Aegean Seas (SE Alpine Europe) Marine.Geology. 196:145-156 
Sivan,D., Wdowinski,S., Lambeck, K., Galili, E., Raban, A., (2001) Holocene sea-level changes along the Mediterranean coast of Israel, based on archaeological observations and numerical model.

Paleogeography, Paleoclimatology, Paleoecology. 167:101-117,

van Andel, Tj. H. and N. Lianos, (1983) "Prehistoric and Historic Shorelines of the Southern Argolid Peninsula: A Subbottom Profiler Study," IJNA 12, pp. 303-324

Yıldız,H.,Demir,C., (2002)Mean sea level changes and vertical crustal movement at Turkish tide gauges for the period of 1984-2001, Workshop on Vertical Crustal Motion and Sea Level Changes. 17-19 September 2002 Toulouse, France 